\title{
BASELINE FINDINGS OF CARENUTRITION INTERVENTION (RCT) AMONG OLDER CAREGIVERS - RISK OF MALNUTRITION AND INSUFFICIENT PROTEIN INTAKE
}

\author{
S. Kunvik ${ }^{1,2}$, R. Valve ${ }^{2}$, K. Salminen ${ }^{1}$, M. Salonoja ${ }^{1}$, M.H Suominen ${ }^{3}$
}

\begin{abstract}
Objectives: Older caregivers are vulnerable to nutritional problems, but only a few studies have examined their nutrition. The purpose of this study was to determine the associations between nutritional status and nutrient intake among older caregivers. Design: Cross-sectional analysis of baseline data from the CareNutrition randomized controlled trial (RCT). Setting: Communitydwelling caregivers from the Western part of Finland in two different clusters. Participants: A total of 79 caregivers aged $\geq 65$ with normal cognition were recruited for the study, all of whom had officially approved caregiver status by The Social Insurance Institution of Finland. Measurement: Nutritional status was assessed by the Mini Nutritional Assessment (MNA), nutrient intake by a three-day food diary, nutrition-related blood markers by laboratory tests, cognition by the Mini Mental State Examination (MMSE), and other baseline characteristics were also evaluated using validated methods. Results: The majority of the caregivers $(79.7 \%$ ) had a good nutritional status (MNA points $>23.5)$, $19 \%$ were at risk of malnutrition (MNA points 17-23.5) and one person $(1.3 \%)$ already suffered from malnutrition (MNA points $<17$ ). The female caregivers were at a higher risk of malnutrition than the males $(26.5 \%$ vs. $6.7 \%, \mathrm{p}=0.026)$. Depressive symptoms and medication were associated with decreased nutritional status, and good health-related quality of life with better nutritional status. Mean protein intake was $1.0 \mathrm{~g} / \mathrm{kg}$ IBW/d and $79.7 \%$ of the caregivers (77.6\% female, $83.3 \%$ male) did not consume the recommended protein intake of $1.2 \mathrm{~g} / \mathrm{kg}$ IBW/ d. Their intake of dietary fibre, folate and vitamin D was also insufficient. Conclusion: Every fifth caregiver was at risk of malnutrition. The females were at a higher risk than the males. Most of the caregivers had insufficient protein intakes. These findings confirm the importance of investigating the nutritional status of older caregivers and indicate a need for preventive nutritional guidance.
\end{abstract}

Key words: Caregiver, nutrition, nutrient intake.

\section{Introduction}

The world's population is ageing, and as a consequence, the number of older people with disabilities and chronic diseases who need support and assistance will increase (1). Informal caregivers provide valuable services to people with long-term care needs. Europe has approximately 100-125 million caregivers (2). In Finland, about 350000 caregivers help their relatives or loved ones, and in 2013, roughly 42500 caregivers received support for informal care from their municipality. Half of these caregivers are $\geq 65$ years old, and every fourth $\geq 75$ years old. More than half are female and the majority take care of their spouses $(3,4)$.

Informal care is extremely important in the context of an ageing population, the increasing pressures on

1. The Social Services and Healthcare Centre of Pori, Finland; 2. Department of Food and Environmental Sciences, University of Helsinki, Finland; 3. Unit of Primary Health Care, Helsinki University Central Hospital, Finland.

Corresponding Author: Susanna Kunvik, The Social Services and Healthcare Centre of Pori, Finland and Department of Food and Environmental Sciences, University of Helsinki, Finland, susanna.kunvik@gmail.com public finances, and rising life expectancy at older ages (5). Concern has been mounting about the health and welfare of people who provide informal care for family or friends with chronic illnesses. Older caregivers are often under a heavy burden and suffer from health problems themselves (6). They are at an increased risk of stress, depression and other health complications that can increase the risk of nutritional problems (7-10). Many factors increase this risk among older caregivers because ageing is accompanied by numerous cognitive, psychological and social factors, which may expose older people to inadequate nutrition and poorer well-being (11).

Studies have found the prevalence of malnutrition in community-dwelling older people to be $1 \%-5 \%$, and one in four to be at risk of malnutrition $(12,13)$. Among older caregivers, the prevalence of malnutrition is around $5 \%$, and about $16 \%-32 \%$ of caregivers are at risk of malnutrition $(14,15)$. Intake of protein is also low $(<1 \mathrm{~g} / \mathrm{kg} / \mathrm{d})$ among older caregivers (16). Insufficient protein intake may contribute to age-related loss of lean muscle mass, which can in turn lead to impaired physical function (17). This can weaken caregivers' ability to 
cope with everyday tasks and the provision of care. To maintain bone mass, muscle mass, and strength, protein intake should be 1.2-1.5 g protein $/ \mathrm{kg} / \mathrm{d}$ (18).

Relatively few studies have assessed the levels of nutritional risk and nutrient intake among community caregivers. Thus, our study aims to examine older ( $\geq 65 \mathrm{y}$ ) caregivers' nutritional status and nutrient intake.

\section{Methods}

\section{Setting}

This cross-sectional study is part of a randomized controlled intervention trial, CareNutrition, which explores the effectiveness of tailored nutritional counselling on protein intake and wellbeing among older caregivers ( $\geq 65 \mathrm{y})$ and people $(\geq 50 \mathrm{y})$ receiving care. In this cross-sectional study, we focus on older caregivers. The study was approved by the Ethics Committee of the Hospital District of Southwest Finland. Informed consent was obtained from the participants. The trial was registered and described at the Australian New Zealand Clinical Trials Registry, Trial Id: ACTRN12615001254583.

\section{Participants}

Caregivers were recruited for the study during nurses' appointments, by inviting them to attend a caregivers' well-being and health screening. These screenings were organized in two clusters; Autumn 2015 and Spring 2016. We invited two groups of caregivers; those who received care allowance from the Services for Disabled People (caregivers $\geq 65$ years) and those who received care allowance from the Services for Older People (caregiver $\geq 40$ years, informal carer $\geq 3$ years). These criteria were decided before this study began, and were based on the recommendations of the Finnish Ministry of Social Affairs and Health. All caregivers had a caregiver status officially approved by The Social Insurance Institution of Finland.

If a caregiver showed an interest in the study during the health screening, a nutritionist made a home visit during which they provided oral and written information about the study. Informed consent was obtained from the caregiver if they fulfilled the inclusion criteria (all criteria had to be fulfilled), which were: age of $\geq 65$ during the study year, informed consent, an officially confirmed caregiver status, living at home, and normal cognition (geriatric assessment MMSE points $\leq 25$, if assessment was needed). If the caregiver participated in the study, the data from the nurse's appointment were used as baseline measurements.

In autumn 2015 and spring 2016, we sent an invitation to a health screening to 368 caregivers, of whom 169 agreed to attend (Figure 1). During the health screening, 92 participants expressed interest in participating in the study. Ten were too young to participate. During the nutritionist's first visit, a further 13 caregivers were excluded from the study for not meeting the inclusion criteria or declining to participate after the interview. A total of 79 caregivers aged $\geq 65$ were recruited for the study.

\section{Figure 1}

Flow chart of participant enrolment

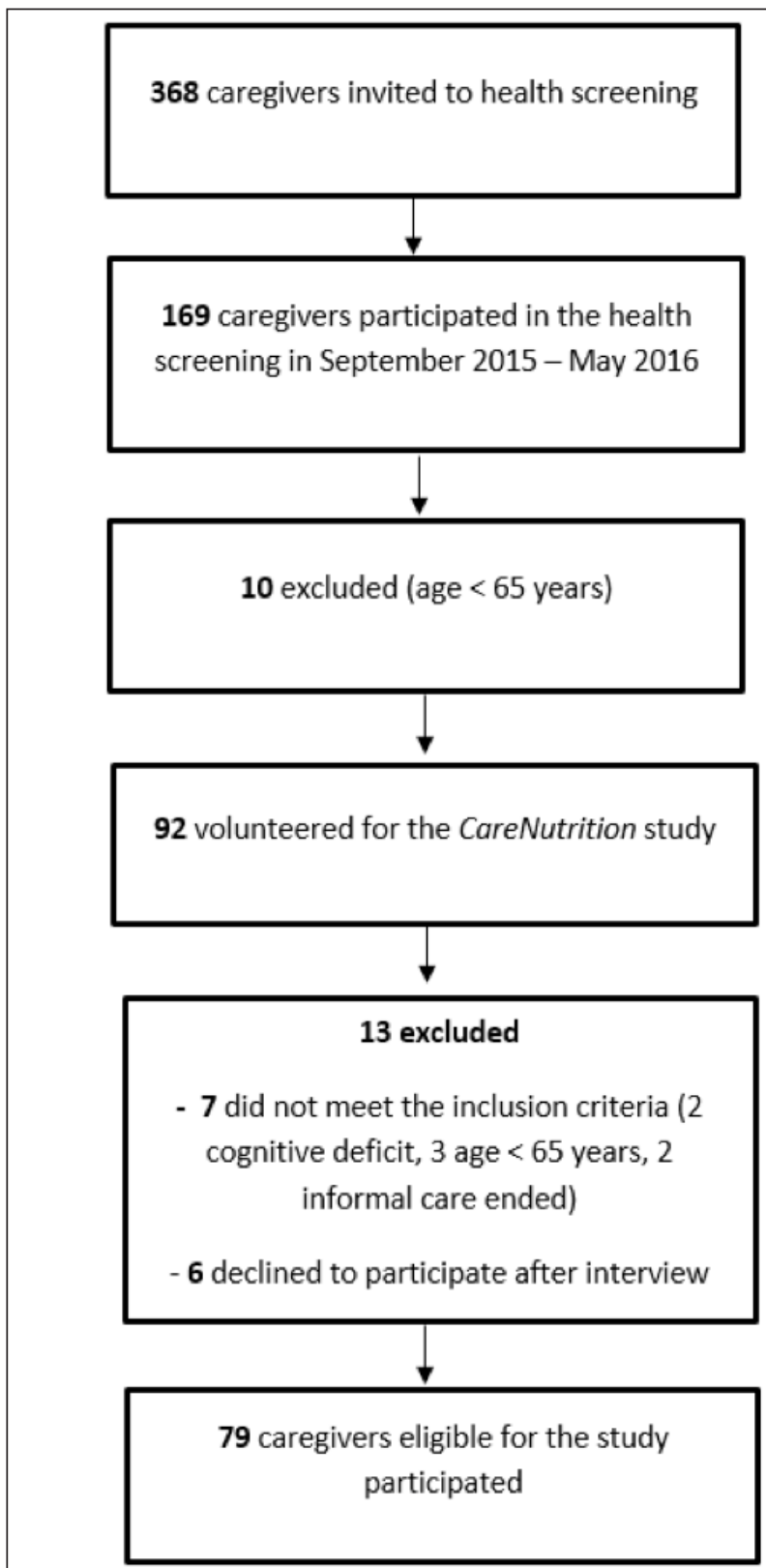

\section{Measurements}

Baseline measurements were taken during two different appointments; the nurse's health screening and the nutritionist's home visit. The nurse's appointment was at the health care centre, with a trained nurse, and included several assessments. Cognition was measured by the MMSE (19), activities of daily living (ADL) by the Katz index (20), instrumental activities of daily 
Table 1

Caregivers' baseline characteristics and nutritional status (MNA)

\begin{tabular}{|c|c|c|c|c|}
\hline Characteristic & All $(n=79)$ & Females $(n=49)$ & Males $(\mathbf{n}=30)$ & P-value \\
\hline Age, mean (SD) & $73.7(6.2)$ & $72.9(5.9)$ & $74.9(6.7)$ & 0.167 \\
\hline Spousal caregiver $(\%)$ & 83.5 & 81.6 & 86.7 & 0.815 \\
\hline \multicolumn{5}{|l|}{ Reason for care (\%) ICD-10 } \\
\hline Mental and behavioural disorders (dementia) ICD-10; F00-F99 & 30.3 & 28.3 & 30.3 & \multirow[t]{2}{*}{0.362} \\
\hline Diseases of the circulatory system ICD-10; I00-I99 & 35.5 & 39.1 & 33.3 & \\
\hline Education years, mean (SD) & $10.1(3.6)$ & $10.1(4.0)$ & $10.1(3.1)$ & 0.874 \\
\hline \multicolumn{5}{|l|}{ MNA categories (\%) } \\
\hline Normal nutritional status, $>23,5 \mathrm{p}$. & 79.7 & 73.5 & 90.0 & \multirow[t]{3}{*}{0.026} \\
\hline At risk of malnutrition, $17-23,5 \mathrm{p}$. & 19.0 & 26.5 & 6.7 & \\
\hline Malnourished, $<17$ p. & 1.3 & 0 & 3.3 & \\
\hline BMI kg/m2, mean (SD) & $28.1(4.5)$ & $27.9(4.0)$ & $28.3(5.2)$ & 0.716 \\
\hline MMSE points, mean (SD) & $27.4(2.4)$ & $27.6(2.3)$ & $27.0(2.6)$ & 0.596 \\
\hline \multicolumn{5}{|l|}{ Depression (GDS-15) } \\
\hline Mean score, $(\mathrm{SD})$ & $2.8(2.6)$ & $3.1(2.6)$ & $2.4(2.5)$ & 0.139 \\
\hline Mild or moderate depression (\%) & 10.1 & 10.2 & 10.0 & \multirow[t]{2}{*}{0.732} \\
\hline Severe depression $(\%)$ & 1.3 & 2.0 & 0 & \\
\hline Number of medications, mean (SD) & $3.9(3.1)$ & $4.0(3.0)$ & $3.7(3.2)$ & 0.518 \\
\hline 15D score (HrQol) & $0.9(0.01)$ & $0.9(0.08)$ & $0.9(0.09)$ & 0.529 \\
\hline ADL points, mean (SD) & $5.9(0.3)$ & $5.9(0.3)$ & $5.9(0.3)$ & 0.455 \\
\hline IADL points, mean (SD) & $7.9(0.3)$ & $8.0(0,3)$ & $7.8(0.4)$ & 0.008 \\
\hline Five Times Sit to Stand Test, seconds, mean (SD) & $13,8(3.3)$ & $14.0(3,4)$ & $13.6(3.2)$ & 0.643 \\
\hline Hand-grip strength, dominating hand (kg) mean (SD) & $30.9(10.8)$ & $25.8(5,9)$ & $39.0(11.8)$ & 0.000 \\
\hline AUDIT, points, mean (SD) & $2.2(2.9)$ & $1.1(1.2)$ & $4.0(3.9)$ & 0.000 \\
\hline Harmful alcohol use (\%), AUDIT & 5.1 & 0 & 13.3 & 0.009 \\
\hline \multicolumn{5}{|c|}{ 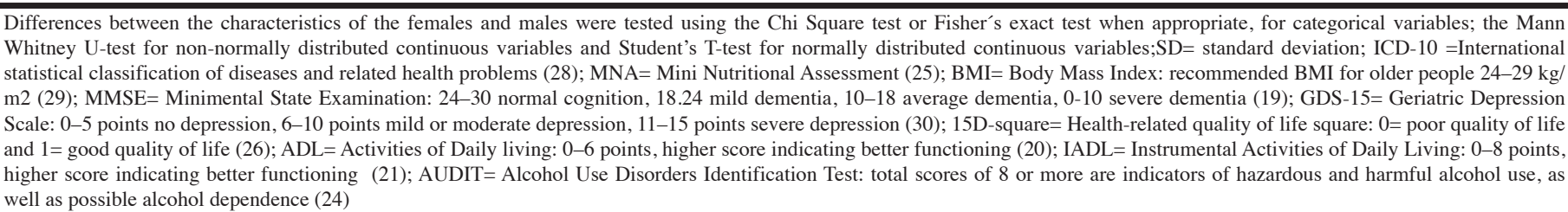 } \\
\hline
\end{tabular}

living (IADL) by the Lawton-Brody questionnaire (21), lower extremity muscle strength by the Five Times Sit to Stand Test (22), depression by the Geriatric Depression Scale (GDS-15) (23), medication by an open question, and harmful alcohol use (alcohol consumption, drinking behaviours, and alcohol-related problems) by the Alcohol Use Disorders Identification Test (AUDIT) (24). An experienced geriatrician reviewed the health screening papers. After the nurse's appointment, a nutritionist made a home visit. Nutritional status was assessed by the MNA (25), health-related quality of life (HRQoL) by the 15D measure (26), and both-hand grip strength (27) using a Jamar Hydraulic Hand Dynamometer (Jamar Bolingbrook IL 60440-4989). The hand-grip strength of each hand was measured two or three times and the best result from the dominating hand was taken as the result. Nutrient intake was assessed via the three-day food diaries that caregivers returned by mail after the nutritionist's home visit. We analysed the food diaries using the Finnish National Food Composition Database, Fineli. Ideal bodyweight (IBW) was used to calculate protein intake $/ \mathrm{kg}$ IBW $/ \mathrm{d}$. If the caregivers' body mass index (BMI) was between $20 \mathrm{~kg} / \mathrm{m} 2$ and $30 \mathrm{~kg} / \mathrm{m} 2$, we used the actual BMI. If BMI was under $20 \mathrm{~kg} / \mathrm{m} 2$, it was adjusted to 20 and if above $30 \mathrm{~kg} / \mathrm{m} 2$, it was adjusted to 30. Nutrition-related laboratory tests of plasma $25(\mathrm{OH}) \mathrm{D}$ vitamin, complete blood count (haemoglobin reported), plasma albumin, and serum prealbumin were conducted in the Satakunta Central Hospital laboratory (SataDiag, Finnish Accreditation Service, standards SFS- 
EN ISO/IEC 17025:2005, SFS-EN ISO 15189:2013) after the nutritionist's visit. Haemoglobin was assessed using a photometric system; serum 25(OH)D vitamin levels using a immunoluminometric system (Advia Centaur) that measures both ergocalciferol and cholecalciferol 25-hydroxylated metabolites; plasma albumin using a photometric (bromocrerol purple method) system; and serum prealbumin using a photometric, immunochemical system. Use of vitamin D supplement was assessed via a questionnaire and the food diaries.

\section{Statistics}

The results are presented as means with standard deviation (SD) or as percentages. Statistical differences between groups were determined by T-tests, the Mann Whitney U-test, the Chi Square test or Fisher's exact test, whichever was appropriate. Associations were analysed by linear regression models (the Enter method) adjusted for age and BMI, and the results are presented as standardized beta coefficients $(\beta)$. P-values less than 0.05 were considered statistically significant. Statistical analyses were carried out using SPSS version 22.0 (SPSS, Inc., Chicago, IL).

\section{Results}

\section{Baseline characteristics}

In 2015-2016, 79 older ( $\geq 65$ y) home-dwelling caregivers - 49 females and 30 males - participated in the study (Table 1). The participation rate was $49.7 \%$ of all the 159 caregivers aged $\geq 65$ who attended the health screening. The caregivers' mean age was 73.7 years, and most of them cared for their spouses. They had good cognition (mean MMSE score 27.4) and had good physical functioning according to their ADL and IADL scores. The mean time in the Five Times Sit to Stand Test was 13.8 seconds. The mean hand-grip strength of the dominating hand was $25.8 \mathrm{~kg}$ among the females and $39.0 \mathrm{~kg}$ among the males. Most of the caregivers were of normal weight (Mean BMI $28 \mathrm{~kg} / \mathrm{m} 2$ ). The mean number of medications was 3.9. Their HRQoL was good (15D score 0.9). According to GDS-15, one in ten $(10.1 \%)$ suffered from mild or moderate depression. The AUDIT results showed that none of the female caregivers had hazardous alcohol use, but $13.3 \%(n=4)$ of the males scored $>8$ AUDIT points, indicating harmful patterns of alcohol consumption, drinking behaviours or alcoholrelated problems.

\section{Nutritional status}

Most of the caregivers (79.7\%) had a good nutritional status (MNA points $>23.5$ ), 19\% were at risk of malnutrition (MNA points 17-23.5) and one person (1.3\%) already suffered from malnutrition (MNA points $<17$ ).
The female caregivers were more likely to be at risk of malnutrition than the males $(26.5 \%$ vs. $6.7 \%, \mathrm{p}=0.026)$. The MNA test showed that the females suffered more psychological stress or acute illnesses than the males, but the difference was not quite statistically significant $(p=0.056)$. Among the females, energy intake was associated with nutritional status, but the result was just above statistical significance $(p=0.056)$. Energy intake was higher $(1707 \mathrm{kcal} / \mathrm{d}$ vs. $1418 \mathrm{kcal} / \mathrm{d})$ among the females who were at risk of malnutrition (MNA $<23.5$ points).

Nutritional status was negatively associated with depression symptoms (GDS-15, $p=0.000, \beta=-0.487$ ): a higher GDS-15 score indicated a lower MNA score. The number of medications was negatively associated with nutritional status $(\mathrm{p}=0.000, \beta=-0.452)$. The association between good HRQoL and nutritional status (15D score, $\mathrm{p}=0.026, \beta=0.336$ ) was positive.

\section{Nutrient intakes}

The caregivers' mean energy intake was $1610 \mathrm{kcal} / \mathrm{d}$ (Table 2.). A total of $46.8 \%$ had an energy intake of under $1500 \mathrm{kcal} / \mathrm{d} ; 26.7 \%$ of the males and $59.2 \%$ of the females. The males had a higher energy intake than the females (1798 kcal vs. $1494 \mathrm{kcal}, \mathrm{p}=0.002)$. Mean protein intake was $69.2 \mathrm{~g} / \mathrm{d}$. Although the males had a higher energy intake, they had less protein calculated as energy $(\mathrm{E} \%)$ than the females (16.6 E\% vs. $18.0 \mathrm{E} \%, \mathrm{p}=0.045)$. Among the male caregivers, a higher total AUDIT score was associated with lower protein intake $\mathrm{g} / \mathrm{kg}$ IBW $/ \mathrm{d}$ $(\mathrm{p}=0.012, \beta=-0.454)$. Greater hand-grip strength was associated with a higher protein intake among the males $(\mathrm{p}=0.031, \beta=0.433)$

For ideal bodyweight (BMI $20-30 \mathrm{~kg} / \mathrm{m} 2$ ), the mean protein intake was calculated as $1.0 \mathrm{~g} / \mathrm{kg} \mathrm{IBW} / \mathrm{d}$. A total of $79.7 \%$ of the caregivers did not consume the recommended protein intake of $1.2 / \mathrm{kg} \mathrm{IBW} / \mathrm{d}$; females $77.6 \%$ and male $83.3 \%$.

Dietary fibre (mean $19.8 \mathrm{~g}$ ), folate (mean $208.1 \mathrm{ug} / \mathrm{d}$ ) and vitamin D (mean $9.3 \mathrm{ug} / \mathrm{d}$ ) intake was insufficient. A total of $83.5 \%$ did not consume the recommended daily intake of dietary fibre, folate $(94.9 \%)$ or vitamin D $(67.1 \%)$.

\section{Laboratory tests}

The caregivers' mean serum 25(OH)D levels were 80.8 $\mathrm{nmol} / \mathrm{l}$. A total of $73.4 \%$ took a vitamin $\mathrm{D}$ supplement. The females were more likely to use supplements than the males $(81.6 \%$ vs. $60.0 \%, \mathrm{p}=0.035)$. The use of a vitamin D supplement was related to serum $25(\mathrm{OH})$ D levels, as the mean vitamin $\mathrm{D}$ status was higher among the caregivers who took a supplement $(84.7 \mathrm{nmol} / 1 \mathrm{vs}$. 69.7 $\mathrm{nmol} / \mathrm{l}, \mathrm{p}=0.035)$. Mean haemoglobin was $138 \mathrm{~g} / \mathrm{l}$, plasma albumin $37.6 \mathrm{~g} / \mathrm{l}$, and serum prealbumin $0.25 \mathrm{mg} / \mathrm{l}$. The males had higher blood haemoglobin than the females $(p=0.002)$. Haemoglobin levels were positively associated with nutritional status ( $\mathrm{p}=0.031$, beta $=0.259$ ). 
Table 2

Baseline results of caregivers' nutrient intakes, vitamin D supplement use and nutrition-related laboratory tests

\begin{tabular}{|c|c|c|c|c|c|}
\hline & All $(n=79)$ & Female $(\mathrm{N}=49)$ & Male $(n=30)$ & p-value & Reference values \\
\hline Total energy kcal/d, mean (SD) & $1610(424)$ & $1494(377)$ & $1798(434)$ & 0.002 & Non-specific \\
\hline Total protein g/d, mean (SD) & $69.2(17.9)$ & $66.3(16.3)$ & $73.9(19.6)$ & 0.069 & Non-specific \\
\hline Protein g/kg IBW / d, mean (SD) & $1.0(0.3)$ & $1.0(0.3)$ & $0.9(0.2)$ & 0.378 & $1.2-14 \mathrm{~g} / \mathrm{kg} / \mathrm{d}^{(1}$ \\
\hline Protein E $\%, \%$ & $17.4(3.1)$ & $18.0(2.9)$ & $16.6(3.1)$ & 0.045 & $15-20 \mathrm{E} \%{ }^{(1}$ \\
\hline Fibre g/d, mean (SD) & $19.8(6.0)$ & $19.2(6.0)$ & $20.7(5.9)$ & 0.269 & $25-35 \mathrm{~g} / \mathrm{d}^{(1}$ \\
\hline Folate $\mu \mathrm{g} / \mathrm{d}$, mean $(\mathrm{SD})$ & $208.1(69.8)$ & $203.3(68.2)$ & $216.0(72.7)$ & 0.374 & $300 \mathrm{ug} / \mathrm{d}^{(1}$ \\
\hline Vitamin D $\mu \mathrm{g} / \mathrm{d}$, mean (SD) & $9.3(5.3)$ & $8.8(5.0)$ & $10.1(5.8)$ & 0.342 & $\begin{array}{l}10 \mathrm{ug} / \mathrm{d}, 61-74 \text { years }{ }^{(1} \\
20 \mathrm{ug} / \mathrm{d}, \geq 75 \text { years }\end{array}$ \\
\hline Use of Vitamin D supplement, $\%$ & $73.4 \%$ & $81.6 \%$ & $60.0 \%$ & 0.035 & Advised to use \\
\hline Serum 25(OH)D nmol / l, mean (SD) & $80.8(29.1)$ & $78.29(25.80)$ & $85.14(33.96)$ & 0.66 & $>50 \mathrm{nmol} / 1^{(2}$ \\
\hline Haemoglobin (g/l) & $138.5(12.3)$ & $135.27(9.44)$ & $143.90(14.63)$ & 0.002 & $\begin{array}{l}\text { 117-155 g/l women, } \\
134-167 \mathrm{~g} / 1 \text { men }^{(3}\end{array}$ \\
\hline Plasma albumin $(\mathrm{g} / \mathrm{l})$ & $37.6(2.5)$ & $37.49(2.52)$ & $37.86(2.42)$ & 0.498 & $34-45 \mathrm{~g} / \mathrm{1}^{(4}$ \\
\hline Serum prealbumin (mg/l) & $0.25(0.04)$ & $0.24(0.040)$ & $0.26(0.05)$ & 0.062 & $0.20-0.40 \mathrm{~g} / 1^{(3}$ \\
\hline
\end{tabular}

Differences between the characteristics of the females and the males were tested using the Chi Square test or Fisher's exact test when appropriate for categorical variables, the Mann Whitney U-test for non-normally distributed continuous variables, and Student's T-test for normally distributed continuous variables. The

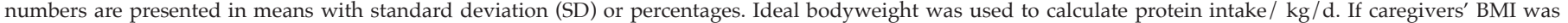

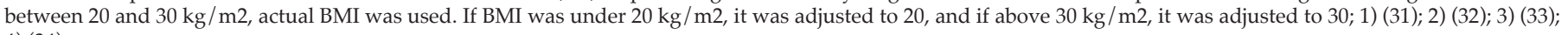
4) (34)

\section{Discussion}

In this study, most of the older ( $\geq 65 \mathrm{y}$ ) caregivers had a good nutritional status, according to the MNA. However, every fifth was at risk of malnutrition, and this risk was more likely among the females. Depressive symptoms and medication were associated with decreased nutritional status, and good HRQoL with better nutritional status. The food diaries showed that most of the caregivers had an insufficient protein intake. Intakes of dietary fibre, folate and vitamin D were also low. Among the males, a higher AUDIT score was associated with a lower protein intake, and greater hand-grip strength with a higher protein intake.

The prevalence of nutritional risk among caregivers in this study is in line with that of previous studies, which have found $16 \%-30 \%$ of older caregivers to be at risk of malnutrition $(14,35)$. This result is interesting, since although the physical performance of the caregivers in our study was good (IADL, ADL), every fifth caregiver was still at risk of malnutrition. Ageing is also accompanied by many cognitive, psychological, and social factors, which may expose older people to inadequate nutrition (11). In this study, depressive symptoms and medication were associated with decreased nutritional status. This result is expected, as depression is believed to be the most common cause of nutritional problems among older people, and the use of medication can affect nutritional status in many ways (36). Caregivers' good HRQoL was associated with better nutritional status. Previous studies have also found a relationship between HRQoL and the risk of malnutrition (37). Caregivers are greatly exposed to depression and poor mental health, which can increase the risk of inadequate nutrition $(8,9,38)$.

The MNA revealed that the female caregivers were more likely to be at risk of malnutrition than the males, as has been found in other studies examining nutrition among older people $(39,40)$. In this study, the result is not explained by a lower energy intake among the females, because the energy intake of females who were at risk of malnutrition was higher. The MNA showed that the females had more psychological stress or acute illnesses than the males, but the differences were not quite statistically significant. The results still indicate, however, that these gender differences may be explained by psychological factors. Only a few studies have investigated the nutritional status of older caregivers, which indicates the need for further research and more systematic assessments.

In this study, the caregivers' protein intake was lower $(1.0 \mathrm{~g} / \mathrm{kg} \mathrm{IBW} / \mathrm{d})$ than is recommended in Finland; $1.2-$ $1.4 \mathrm{~g} / \mathrm{kg} / \mathrm{d}$ (31). Approximately $80 \%$ of the caregivers did not consume the recommended intake of $1.2 \mathrm{~g} / \mathrm{kg} / \mathrm{d}$, which is a concern. The male caregivers consumed less protein than the female caregivers when calculated as energy, but their protein $\mathrm{E} \%$ was still in line with the recommendations in Finland; 15-20 E\% (31). Adequate protein intake is known to play an important role in the immune system, bone mass density, muscle function, strength, and the management of sarcopenia (17, 41, 42). It is estimated that an intake of 1,2 to $1.6 \mathrm{~g} / \mathrm{kg} \mathrm{BW} / \mathrm{d}$ may be required for older people to preserve muscle 
mass $(18,43)$. In this study, greater hand-grip strength was associated with a higher protein intake. Adequate protein intake is important for older caregivers, since they need to stay in relatively good physical shape to be able to take care of another person. Increasing protein intake may help maintain muscle strength and help prevent mobility impairment (44). There is a need for preventive nutritional guidance that specifically focuses on increasing the protein intake of older caregivers.

Among the males, a higher AUDIT score was associated with a lower protein intake. AUDIT is a screening tool for alcohol consumption, drinking behaviour, and alcohol-related problems (24). Our result was analysed using the overall AUDIT score, which may not be the proper way to use this test, as the result is usually classified into different risk categories. Moreover, the moderate alcohol consumption in this population meant that we were unable to obtain the same result when alcohol consumption was categorized as $0-7$ and $>8$ AUDIT points. However, the result is still interesting, because it is known that alcohol consumption is related to eating habits (45). Harmful alcohol consumption among older people may accompany nutritional problems, as it replaces the consumption of foods with superior nutritional value (46).

The caregivers had a poor intake of folate and dietary fibre, as found in previous studies among older caregivers (16). These findings indicate a low intake of fruits, vegetables and whole grain products. Stress can affect eating habits and may be shown in the consumption of vegetables. A study by Shaffer et al. (47) found that cancer-related stress was associated with a low consumption of vegetables among cancer-patients and their caregivers. Nutritional guidance can help increase the use of products rich in fibre and vitamins (48). The average vitamin D intake from food was below the recommended level. Still, the caregivers' mean plasma $25-\mathrm{OH}$-vitamin D levels were good $(80.8 \mathrm{nmol} / 1)$ in comparison to the results from the UK National Diet and Nutrition Survey 2008-2012, in which the year-round mean plasma $25(\mathrm{OH}) \mathrm{D}$ concentration was $42.5 \mathrm{nmol} / 1$ among $>65$-year-old females (49). The use of vitamin D supplements was related to higher plasma 25-OH-vitamin D levels, which highlights the clinical value of vitamin D supplements among the older population.

The strength of our study is that it provides information regarding the nutritional status and nutrient intake of older caregivers, information that is generally lacking. We used validated methods to assess their nutritional status. The MNA has been validated for older adults $(25,50)$ and has been used in large populations (51). We also obtained information on caregivers' nutrient intakes and 25(OH)D levels, which are not usually reported.

Nevertheless, our study has some potential limitations. Due to its cross-sectional nature, causal relationships cannot be drawn from the results. Because of the specifity of our recruitment, the number of participants was small and the study population was selected. This weakens the generalizability of our results to other older caregivers. Selection bias is also possible because the participants were in good physical shape and were keen to participate. This may indicate that they were more health conscious than the average elderly population, and the study results may be more optimistic than in reality. The study population consisted of both females and males, which improved the sample. Some other limitations are related to the measurements. Nutrient intake was studied using three-day food diaries, which can affect the results through over- or under-reporting. This time may not be long enough to show the actual food intake over a longer period. However, we performed check calls to confirm the amounts and types of foods consumed, and it is still noteworthy that the participants had fairly stable food habits, as older people usually do.

Nutritional well-being is a fundamental component of health, physical functioning and quality of life (52). Older caregivers have shown to be prone to malnutrition (16) so they need special support for their nutritional wellbeing.

\section{Conclusion}

Our results showed that most of the older ( $\geq 65 \mathrm{y}$ ) caregivers had good nutritional status, but that one in five was still at risk of malnutrition, especially among the females. Depressive symptoms and medication were associated with decreased nutritional status, and good HRQoL with better nutritional status. A total of $79.7 \%$ of the caregivers had a lower protein intake than that recommended. The intake of dietary fibre, folate and vitamin $\mathrm{D}$ were also low. Among the males, a greater AUDIT score was associated with a lower protein intake, and greater hand-grip strength with a higher protein intake. These results highlight the need for systematic nutritional assessment among older caregivers and the importance of preventive nutritional guidance. Further studies are required to obtain more information about older caregivers' nutritional statuses and nutrient intake.

Funding/Support: This study received funding from the National Institute for Health and Welfare (THL) in Finland. The funders played no role in the design, analysis or interpretation of the data or in writing, reporting or deciding whether to submit this article for publication. The authors are independent researchers and are not associated with the funders.

Conflict of interest: The authors declare that they have no conflicts of interest directly relevant to this report. However, Dr Suominen reports co-operating professionally with Nutricia Medical and Verman.

Ethical standards: The Ethics Committee of the Hospital District of Southwes Finland approved the study and participants provided written informed consent.

\section{References}

1. Torres MJ, Dorigny B, Kuhn M, Berr C, Barberger-Gateau P, Letenneur L Nutritional status in community-dwelling elderly in France in urban and rural areas. PLoS One 2014;9:e105137. doi: 10.1371/journal.pone.0105137.

2. European Foundation for the Improvement of Living and Working Conditions, 2009. Second European Quality of Life Survey. Overview. Luxembourg. Office for Official Publications of the European Communities. http:/ / www. eurofound.europa.eu/pubdocs/2009/02/en/2/EF0902EN.pdf. Accessed 26 
January 2017.

3. Finnish Ministry of Social Affairs and Health, 2014. National informal care development programme, final report. https://www.julkari.fi/bitstream/ handle / 10024/116146/URN_ISBN_978-952-00-3483-2.pdf? sequence=1. Accessed 26 January 2017.

4. The Central Association of Carers in Finland, 2015. Am I a Carer? First-Hand Guide to Informal Care. https://www.omaishoitajat.fi/sites/omaishoitaja. asiakas.fi/ files/ensiopas_EN_low_3.pdf. Accessed 26 January 2017.

5. Robards J, Vlachantoni A, Evandrou M, Falkingham J. Informal caring in England and Wales--Stability and transition between 2001 and 2011. Adv Life Course Res 2015;24:21-33. doi: 10.1016/j.alcr.2015.04.003.

6. Doran T, Drever F, Whitehead M. Health of young and elderly informal carers. BMJ 2003;327:1388. doi: 10.1136/bmj.327.7428.1388

7. Schulz R, Martire LM. Family caregiving of persons with dementia: prevalence, health effects, and support strategies. Am J Geriatr Psychiatry 2004;12:240-249.

8. Sorensen S, Pinquart M, Duberstein P. How effective are interventions with caregivers? An updated meta-analysis. Gerontologist 2002;42:356-372.

9. Aggarwal B, Liao M, Christian A, Mosca L. Influence of caregiving on lifestyle and psychosocial risk factors among family members of patients hospitalized with cardiovascular disease. J Gen Intern Med 2009;24:93-98. doi: 10.1007/ s11606-008-0852-1.

10. Alzheimer's Disease International, 2010. World Alzheimer Report. The global economic impact of dementia. http://www.alz.co.uk/research/files / WorldAlzheimerReport2010.pdf. Accessed 6 January 2017.

11. Suominen $\mathrm{MH}$ et al. Working Group Report, State Nutrition Council, Nutrition Recommendations for Elderly. Edita Prima, Helsinki 2010

12. Guigoz Y, Lauque S, Vellas BJ. Identifying the elderly at risk for malnutrition. The Mini Nutritional Assessment. Clin Geriatr Med 2002;18:737-757.

13. Guigoz Y. The Mini Nutritional Assessment (MNA) review of the literature-What does it tell us? J Nutr Health Aging 2006;10:466-85; discussion 485-7.

14. Suominen $\mathrm{MH}$, Puranen T, Jyväkorpi S. Ravitsemus muistisairaan kodissa. Loppuraportti. Suomen Muistiasiantuntijat ry 2013.

15. Rullier L, Lagarde A, Bouisson J, Bergua V, Torres M, Barberger-Gateau P. Psychosocial correlates of nutritional status of family caregivers of persons with dementia. Int Psychogeriatr 2014;26:105-113. doi: 10.1017/S1041610213001579.

16. Puranen T. Intervening nutrition among community-dwelling individuals with Alzheimer's disease and their spouses. University of Helsinki, Faculty of Medicine, 2015.

17. Wolfe RR. The role of dietary protein in optimizing muscle mass, function and health outcomes in older individuals. Br J Nutr 2012;108 Suppl 2:S88-93. doi: $10.1017 /$ S0007114512002590.

18. Pedersen AN, Cederholm T. Health effects of protein intake in healthy elderly populations: a systematic literature review. Food Nutr Res 2014;58:10.3402/fnr. v58.23364. doi: 10.3402 / fnr.v58.23364.

19. Folstein MF, Folstein SE, McHugh PR. "Mini-mental state". A practical method for grading the cognitive state of patients for the clinician. J Psychiatr Res 1975;12:189-198. doi: 0022-3956(75)90026-6.

20. Katz S, Ford AB, Moskowitz RW, Jackson BA, Jaffe MW. Studies of Illness in the Aged. the Index of Adl: a Standardized Measure of Biological and Psychosocial Function. JAMA 1963;185:914-919

21. Lawton MP, Brody EM. Assessment of older people: self-maintaining and instrumental activities of daily living. Gerontologist 1969;9:179-186

22. Bohannon RW. Reference values for the five-repetition sit-to-stand test: a descriptive meta-analysis of data from elders. Percept Mot Skills 2006;103:215222. doi: $10.2466 /$ pms.103.1.215-222.

23. Yesavage JA, Brink TL, Rose TL, Lum O, Huang V, Adey M, Leirer VO Development and validation of a geriatric depression screening scale. J Psychiatr Res 1983;17:37-49

24. Saunders JB, Aasland OG, Babor TF, de la Fuente JR, Grant M. Developmen of the Alcohol Use Disorders Identification Test (AUDIT): WHO Collaborative Project on Early Detection of Persons with Harmful Alcohol Consumption--II. Addiction 1993:88:791-804

25. Vellas B, Guigoz Y, Garry PJ, Nourhashemi F, Bennahum D, Lauque S, Albarede JL . The Mini Nutritional Assessment (MNA) and its use in grading the nutritional state of elderly patients. Nutrition 1999;15:116-122. doi: S08999007(98)00171-3.

26. Sintonen $\mathrm{H}$. The $15 \mathrm{D}$ instrument of health-related quality of life: properties and applications. Ann Med 2001;33:328-336

27. Roberts HC, Denison HJ, Martin HJ, Patel HP, Syddall H, Cooper C, Sayer AA. A review of the measurement of grip strength in clinical and epidemiological studies: towards a standardised approach. Age Ageing 2011;40:423-429. doi: 10.1093 / ageing/afr051.

28. World Health Organization, 2016. International statistical classification of diseases and related health problems. Available: http://apps.who.int/ classifications/icd10/browse/Content/statichtml/ICD10Volume2_en_2016. pdf?ua $=1 \& u a=1$. Accessed 14 February 2017

29. Beck AM, Ovesen L. At which body mass index and degree of weight loss should hospitalized elderly patients be considered at nutritional risk? Clin Nutr 1998;17:195-198. doi: S0261-5614(98)80058-7.

30. Friedman B, Heisel MJ, Delavan RL. Psychometric properties of the 15-item geriatric depression scale in functionally impaired, cognitively intact, community-dwelling elderly primary care patients. J Am Geriatr Soc
2005:53:1570-1576. doi: JGS53461.

31. Finnish Nutrition Recommendations. National Nutrition Council. Health from food - The Finnish Dietary Guidelines, 2014.

32. Nordic Council of Ministers, Nordic Council of Minister, 2012. Nordic Nutrition Recommendations http:/ / dx.doi.org/10.6027/Nord2014-002.

33. Satakunta Central Hospital laboratory Satadiag, 2017. Research manual. Satahttp:/ / webohjekirja.mylabservices.fi/SataDiag/?fp=1. Assessed 7.2.2017.

34. Rustad P, Felding P, Franzson L, Kairisto V, Lahti A, Martensson A, Hyltoft Petersen P, Simonsson P, Steensland H, Uldall A. The Nordic Reference Interval Project 2000: recommended reference intervals for 25 common biochemical properties. Scand J Clin Lab Invest 2004;64:271-284. doi: $10.1080 / 00365510410006324$

35. Rullier L, Lagarde A, Bouisson J, Bergua V, Barberger-Gateau P. Nutritional status of community-dwelling older people with dementia: associations with individual and family caregivers' characteristics. Int J Geriatr Psychiatry 2013;28:580-588. doi: 10.1002 /gps.3862.

36. John BK, Bullock M, Brenner L, McGaw C, Scolapio JS. Nutrition in the elderly. Frequently asked questions. Am J Gastroenterol 2013;108:1252-66; quiz 1267. doi: 10.1038 / ajg.2013.125.

37. Jimenez-Redondo S, Beltran de Miguel B, Gavidia Banegas J, Guzman Mercedes L, Gomez-Pavon I, Cuadrado Vives C. Influence of nutritional status on health-related quality of life of non-institutionalized older people. J Nutr Health Aging 2014;18:359-364. doi: 10.1007/s12603-013-0416-x.

38. Hiel L, Beenackers MA, Renders CM, Robroek SJ, Burdorf A, Croezen S. Providing personal informal care to older European adults: should we care about the caregivers' health? Prev Med 2015;70:64-68. doi: 10.1016/j. ypmed.2014.10.028.

39. Cuervo M, Garcia A, Ansorena D, Sanchez-Villegas A, Martinez-Gonzalez M, Astiasaran I, Martinez J. Nutritional assessment interpretation on 22,007 Spanish community-dwelling elders through the Mini Nutritional Assessment test. Public Health Nutr 2009;12:82-90. doi: 10.1017/S136898000800195X.

40. Wham CA, McLean C, Teh R, Moyes S, Peri K, Kerse N. The BRIGHT Trial: what are the factors associated with nutrition risk? J Nutr Health Aging 2014;18:692-697. doi: 10.1007/s12603-014-0032-4.

41. Morley JE, Argiles JM, Evans WJ, Bhasin S, Cella D, Deutz NE, Doehner W, Fearon KC, Ferrucci L, Hellerstein MK et al. Nutritional recommendations for the management of sarcopenia. J Am Med Dir Assoc 2010;11:391-396. doi: 10.1016/j.jamda.2010.04.014.

42. Bauer J, Biolo G, Cederholm T, Cesari M, Cruz-Jentoft AJ, Morley JE, Phillips S, Sieber C, Stehle P, Teta D et al. Evidence-based recommendations for optimal dietary protein intake in older people: a position paper from the PROT-AGE Study Group. J Am Med Dir Assoc 2013;14:542-559. doi: 10.1016/j. jamda.2013.05.021.

43. Lancha AH,Jr, Zanella R,Jr, Tanabe SG, Andriamihaja M, Blachier F. Dietary protein supplementation in the elderly for limiting muscle mass loss. Amino Acids 2017;49:33-47. doi: 10.1007/s00726-016-2355-4.

44. McLean RR, Mangano KM, Hannan MT, Kiel DP, Sahni S. Dietary Protein Intake Is Protective Against Loss of Grip Strength Among Older Adults in the Framingham Offspring Cohort. J Gerontol A Biol Sci Med Sci 2016;71:356-361. doi: $10.1093 /$ gerona/glv184

45. Kesse E, Clavel-Chapelon F, Slimani N, van Liere M, E3N Group. Do eating habits differ according to alcohol consumption? Results of a study of the French cohort of the European Prospective Investigation into Cancer and Nutrition (E3N-EPIC). Am J Clin Nutr 2001;74:322-327.

46. Satre DD, Sterling SA, Mackin RS, Weisner C. Patterns of alcohol and drug use among depressed older adults seeking outpatient psychiatric services. Am J Geriatr Psychiatry 2011;19:695-703. doi: 10.1097/JGP.0b013e3181f17f0a.

47. Shaffer KM, Kim Y, Llabre MM, Carver CS. Dyadic associations between cancer-related stress and fruit and vegetable consumption among colorectal cancer patients and their family caregivers. J Behav Med 2016;39:75-84. doi: 10.1007 / s10865-015-9665-y.

48. Jyväkorpi $\mathrm{S}$ et al. Nutrition education and cooking classes improve diet quality, nutrient intake, and psychological well-being of home-dwelling older people-a pilot study." J Aging Res Clin 2014;3:120-124

49. Bates B, Lennox A, Prentice A, et al, 2014. London: Public Health England, Food Standards Agency National Diet and Nutrition Survey Results from Years 1, 2, 3 and 4 (combined) of the Rolling Programme (2008/2009-2011/2012)

50. Vellas B, Villars H, Abellan G, Soto ME, Rolland Y, Guigoz Y, Morley JE, Chumlea W, Salva A, Rubenstein LZ et al. Overview of the MNA--Its history and challenges. J Nutr Health Aging 2006;10:456-63; discussion 463-5

51. Kaiser MJ, Bauer JM, Ramsch C, Uter W, Guigoz Y, Cederholm T, Thomas DR, Anthony PS, Charlton KE, Maggio M et al. Frequency of malnutrition in older adults: a multinational perspective using the mini nutritional assessment. J Am Geriatr Soc 2010;58:1734-1738. doi: 10.1111/j.1532-5415.2010.03016.x.

52. Phillips MB, Foley AL, Barnard R, Isenring EA, Miller MD. Nutritional screening in community-dwelling older adults: a systematic literature review. Asia Pac J Clin Nutr 2010;19:440-449 